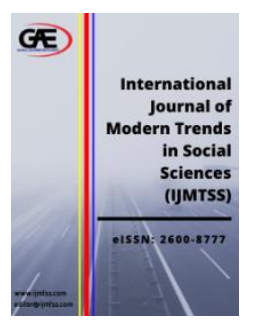

\author{
INTERNATIONAL JOURNAL OF \\ MODERN TRENDS IN \\ SOCIAL SCIENCES \\ (IJMTSS) \\ WWW.ijmtss.com
}

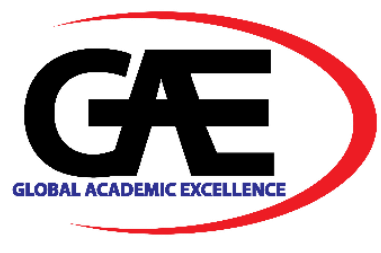

\title{
THE INFLUENCE OF ORGANIZATIONAL COMMITMENT TOWARDS JOB SATISFACTION AMONG POLYTECHNIC STAFF
}

Muhamad Saufiyudin Omar ${ }^{1 *}$, Nurasyikin Mohd Salleh ${ }^{2}$, Siti Fatimah Abdul Aziz

1 Department of Tourism \& Hospitality, Politeknik Tuanku Syed Sirajuddin, Pauh Putra, 02600 Arau, Perlis, Malaysia

Email: saufiyudin@yahoo.com

2 Department of Tourism \& Hospitality, Politeknik Tuanku Syed Sirajuddin, Pauh Putra, 02600 Arau, Perlis, Malaysia

Email: sallehnurasyikin@gmail.com

3 Department of Tourism \& Hospitality, Politeknik Sultan Idris Shah, Sungai Lang, 45100 Sungai Air Tawar, Selangor Darul Ehsan, Malaysia, Malaysia

Email: sitifatimah@psis.edu.my

* Corresponding Author

\section{Article Info:}

\section{Article history:}

Received date: 12.07 .2020

Revised date: 14.07.2020

Accepted date: 13.09.2020

Published date: 10.09.2020

\section{To cite this document:}

Omar, M. S., Salleh, N. M., \& Aziz, S. F. A. (2020). The Influence Of Organizational Commitment Towards Job Satisfaction Among Polytechnic Staff. International Journal of Modern Trends in Social Sciences, 3 (13), 0108 .

DOI: $10.35631 /$ IJMTSS. 313001

\begin{abstract}
:
Organizational commitment is identified as a critical factor that is closely associated with job satisfaction. A limited number of studies have been done to look into the influence of organizational commitment on job satisfaction among Polytechnic staff. Therefore, this study aims to examine the influence of organizational commitment and job satisfaction. A quantitative study was conducted, and stratified random sampling was employed to collect data. Questionnaires were distributed and answered by 130 respondents. The findings reveal that organizational commitment that comprises normative commitment, continuance commitment and affective commitment significantly and positively impacts job satisfaction. This suggests that improving the organizational commitment, more specifically, the normative commitment, continuance commitment, and affective commitment among Polytechnic staff is critically important to enhance their job satisfaction.
\end{abstract}

Keywords:

Organization Commitment; Job Satisfaction; Polytechnic Staffs 


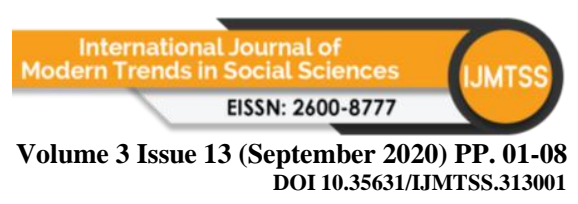

\section{Introduction}

Job satisfaction is crucial in determining the success of an organization. According to Miah (2018), an organization must realize the importance of job satisfaction among employees. Satisfied employees are usually happy and motivated to do their job, and they perform better (Miah, 2018). Meanwhile, dissatisfied employees usually do not try their best and fail to do their job at an optimal level (Setiawan \& Gunawan, 2018). Organizational commitment is identified as one of the key factors that influence employee job satisfaction (Culibrk, Delic, Mitrovic \& Culibrk 2018). According to Greenberg and Baron (2008), organizational commitment is defined as how far the employees relate to the organization they work in, their engagement level in the organization and if they are willing to leave it. Commonly, employees with higher organizational commitment are more likely to stay in their job and the strong emotion that they have will make them loyal and ready to contribute more for the organization (Culibrk et al., 2018). Many research findings have shown the close relationship between organizational commitment and job satisfaction (Sengur \& Turhan, 2018). Therefore, a study on the influence of organizational commitment on job satisfaction among Polytechnic staff is critically important.

In this light, Polytechnic staffs may gain higher job satisfaction if they are happier with their working environment and have more positive attitude towards their job. However, most of the staff carry heavy workload, whereby they are not only educating students, but also carry out various management tasks that may lead to dissatisfaction. In addition, the staff also need to multitask, switching between the academic and non-academic tasks to ensure the organization can run smoothly. As mentioned by Kalleberg (1977) an employee may be satisfied with one or some of the job responsibilities he or she has but dissatisfied with the other tasks in hand. Hence, a study on Polytechnic staff's job satisfaction is crucial to improve their job satisfaction and ensure the organization can always operate in a smooth way.

Polytechnic Malaysia is one of the hubs for the nation's human capital development (Jaafar, 2013). Its role has been expanded and its establishment has been rebranded in making sure the nation's missions are accomplished by providing the human capital source to the industrial sectors to generate economic growth (Jabatan Pengajian Politeknik, 2009). Furthermore, Polytechnic Malaysia focused on the skill-based subjects related to technical and vocational education and training (TVET) that have been improvised and improved in order to be in line with the national plan in achieving Vision 2020 (Abdullah \& Majid, 2013). Hence, a study on human capital especially the teaching staff is critically important due to the high demand and challenges faced by the Polytechnic lecturers in teaching the targeted skill to the future students.

Many researches have studied the association between organizational commitment and job satisfaction (Ahmad \& Jameel, 2018; Culibrk et al., 201S; Sengur \& Turhan, 2018). However, very limited studies focused on the relationship between organizational commitment and job satisfaction among Polytechnic staff especially in the Malaysian context (Abdullah \& Majid, 2013; Kumar \& Muniandy, 2012). Thus, this paper aims to investigate the influence between organizational commitment and job satisfaction. Organizational commitment that is studied here comprises affective commitment, continuance commitment and normative commitment. This study will be useful in increasing the job satisfaction level among the staff besides enriching the body of knowledge in that particular area. Besides that, it can 


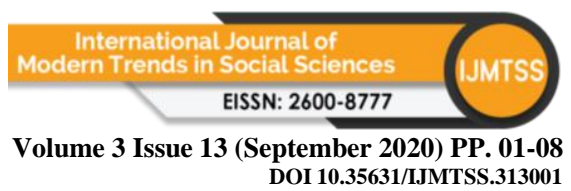

be used as a guideline for the Head of Department (HoD) and management team to enhance the staff job satisfaction.

\section{Literature Review}

\section{Organizational Commitments}

The concept of organizational commitment has been the key focus area in many researches. Organizational commitment is defined as the way the employees feel connected to the organization (Mowday, Steers \& Porter, 1979). Organizational commitment is also referred as the extent to which an individual stand with the organization's values and works towards that by carrying out their job responsibilities (Tanriverdi, 2005). Employees with lower less organizational commitment are more likely to make mistakes at work and commit more absenteeism at work (Mete, Sokinen \& Biyik 2016).

According to Mowday et al. (1979), organizational commitment is a multidimensional construct that comprises affective commitment, continuance commitment, and normative commitment. According to Meyer and Allen (1991), affective commitment is the employee's emotional attachment to the organization. Usually, employees with a higher level of affective commitment are expected to more contented in the organization. These employees will also choose to continue serving the organization as they accept the objectives of the organization (Culibrk et al., 2018).

According to Allen and Meyer (1996), continuance commitment is considered as a propensity to be involved in procedures relying on the individual's perceived costs or profits connected with continued involvement or losses connected with leaving the organization. Individuals with a higher level of continuance commitment tend to contribute for the organization because they perceive it to be for the benefit of them (Valaei \& Rezaei, 2016). Whereas normative commitment is defined as the employee's readiness to serve the organization because of the employee's sense of responsibility (Meyer et al., 1993). This explains that the employee believes that it is obligatory to stay in the organization because it reflects the moral value in them (Werang \& Agung, 2017).

Many studies found that organizational commitment was closely related to job satisfaction. Culibrk et al. (2018) stated that organizational commitment was connected to job satisfaction in a positive way. Chi, Yeh and Nguyen (2018) mentioned that there was a notable association between organizational commitment and job satisfaction. It is found that employees who are more committed to the organization are possibly more contented with their jobs and are ready to contribute more to the organization. Safi et al. (2015) also found that the elements of affective and normative commitment have significant connection with job satisfaction.

\section{Job Satisfaction}

Job satisfaction is defined as an individual's attitude about his/her job and this can be either a positive or negative attitude (Robbins, 1959). Job satisfaction can also be referred to as the general attitude of individuals towards work. For instance, a person with a higher level of job satisfaction will be more positive towards his work (Toban \& Sjahruddin, 2016). Job satisfaction has been an important area in organizational researches because it determines the employees' identification and level of participation or attachment to their organization, and work absenteeism and retention. On the other hand, job satisfaction has been one of the main areas of research for many years because it is believed that it can lead to better job performance, Copyright (C) GLOBAL ACADEMIC EXCELLENCE (M) SDN BHD - All rights reserved 
happier workers, and higher work commitment in an institution. Job satisfaction may be achieved if the employees are satisfied with certain aspects of their job, for instance, the management style, work culture and the empowerment of teamwork (Awang \& Ahmad, 2010).

\section{Hypothesis and Conceptual Framework}

The independent variable in this study was the organizational commitment that comprises affective commitment, continuance commitment and normative commitment. While the dependent variable was job satisfaction. Therefore, this study formulated that:

Hypothesis 1: Affective commitment influence job satisfaction of the Polytechnic employees. Hypothesis 2: Continuance commitment influence job satisfaction of the Polytechnic employees.

Hypothesis 3: Normative commitment influence job satisfaction of the Polytechnic employees.

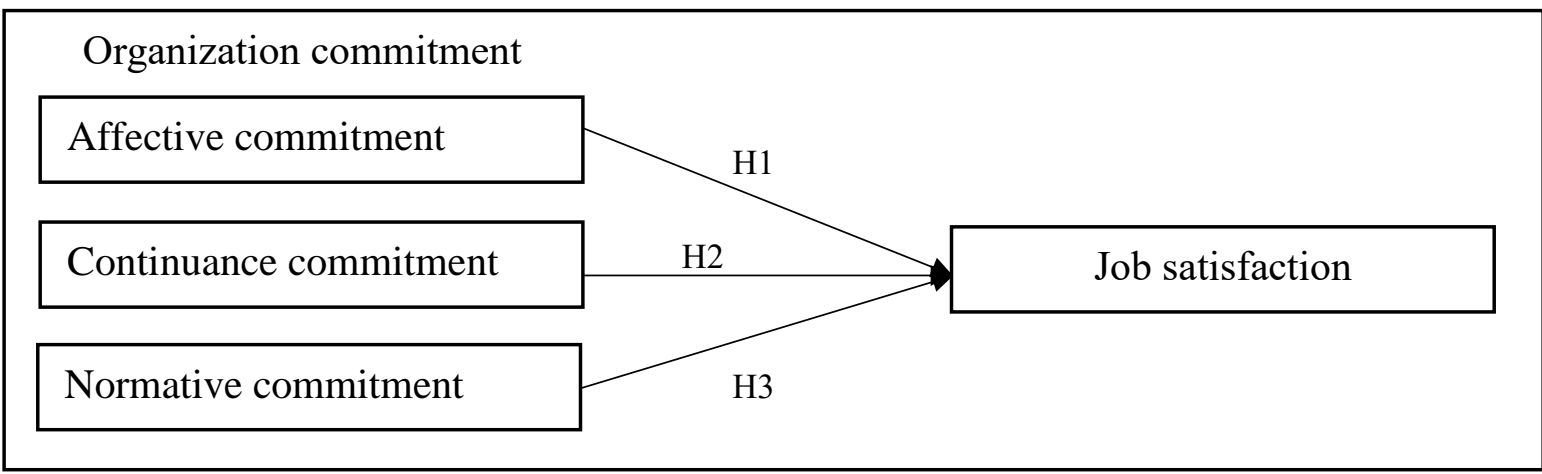

\section{Methodology}

Figure 1: Conceptual Framework

This study employed a quantitative approach including a survey to collect data. The population of this research was the lecturers who work in the Department of Tourism and Hospitality at Polytechnic Malaysia. They are civil servants and most of them have been working for more than six years. In terms of sampling method, the stratified random sampling was employed to distribute 169 survey questionnaires to the staff in the organization. Out of the 169 samples, only 130 responded on the survey and gave a response rate of $77 \%$.

The study has adapted its questionnaire from previous researchers. The organizational commitment questionnaire was adapted from Meyer and Allen (1991) and the job satisfaction questionnaire adapted from Brayfield and Rothe (1951). These adaptations were required to be made in order to make the questionnaire more suitable for this study. The questionnaire consisted of three parts; Part A: Demographic profile (7 items), Part B: Organizational commitment (24 items) and Part C: Job satisfaction (18 items). A five-point Likert scale was employed to indicate their agreement ranging from '1-Strongly disagree' to '5-Strongly agree' to measure the variables and SPSS was used to analyze the data. The reliability values for organizational commitment and job satisfaction were 0.8533 and 0.901 respectively. While the reliability results of the organizational commitment dimensions were affective commitment $=$ 0.792 ; continuance commitment $=0.836$ and normative commitment $=0.759$.

In terms of data collection, the questionnaire was started with a letter from the researchers to inform the respondents about the study objectives and assure them that all data gathered will be kept strictly confidential. In addition, the respondents were also informed that the questionnaire can be completed in approximately 10 minutes. The respondents were given the 
self-administered questionnaire to be completed and their involvement was on a voluntary basis.

\section{Results}

\section{Respondents Demography}

Results reveal that more female respondents $(74.6 \%)$ completed the questionnaire compared to the male respondents $(25.4 \%)$. Majority of respondents were under the age group of 31-40 years old $(69.2 \%)$, followed by those between $41-50$ years old $(25.4 \%)$ and the remaining were between 51-60 years old (0.8\%). The respondents were mostly Malays (99.2\%), and the remaining were of other races $(0.8 \%)$. Most of the respondents have been working for almost $11-15$ years $(44.6 \%)$, followed by $6-10$ years $(32.3 \%)$ and 15 years and above $(13.5 \%)$. The largest group of respondents were 39 employees from PTSS and PSIS that represented 30.0\% from each, followed by 36 employees (27.7\%) from PMM and lastly 16 employees (12.3\%) from $\mathrm{PMKu}$. Table 1 shows the respondents' demographic profile.

Table 1: Demographic Profile of Respondents

\begin{tabular}{llll}
\hline Demographic variables & Category & Frequency & Percentage (\%) \\
\hline Gender & Male & 33 & 25.4 \\
Age & Female & 97 & 74.6 \\
& $21-30$ years old & 6 & 4.6 \\
& $31-40$ years old & 90 & 69.2 \\
& $41-50$ years old & 33 & 25.4 \\
Race & $51-60$ years old & 1 & .8 \\
& Malay & 129 & 99.2 \\
Job Tenure & Others & 1 & .8 \\
& 1-5 years & 12 & 9.2 \\
& 6-10 years & 42 & 32.3 \\
Polytechnics & 11-15 years & 58 & 44.6 \\
& 15 years and above & 18 & 13.8 \\
& PTSS & 39 & 30.0 \\
& PSIS & 39 & 30.0 \\
& PMKu & 16 & 12.3 \\
& PMM & 36 & 27.7 \\
\hline
\end{tabular}

\section{Correlation analysis}

The Pearson correlation analysis showed the relationship between organizational commitment (affective commitment, continuance commitment, normative commitment) and job satisfaction. The results showed that there was a positive relationship between organizational commitment and job satisfaction at a significant level of 0.01 . More specifically, the value between affective commitment and job satisfaction was $\mathrm{r}=0.345, \mathrm{p}<0.001$, continuance commitment and job satisfaction were $r=0.276, p<0.001$, and normative commitment and job satisfaction was $\mathrm{r}=0.374, \mathrm{p}<0.001$. Based on the findings, the strongest positive correlation on job satisfaction was the normative commitment, followed by affective commitment and lastly was continuance commitment. Table 2 shows the correlation analysis between organizational commitment and job satisfaction. 
Table 2: Correlation Analysis of Study

\begin{tabular}{lllll}
\hline & $\begin{array}{l}\text { Affective } \\
\text { commitment }\end{array}$ & $\begin{array}{l}\text { Continuance } \\
\text { commitment }\end{array}$ & $\begin{array}{l}\text { Normative } \\
\text { commitment }\end{array}$ & $\begin{array}{l}\text { Job } \\
\text { satisfaction }\end{array}$ \\
\hline $\begin{array}{l}\text { Affective commitment } \\
\text { Continuance }\end{array}$ & & & & \\
commitment & $.272^{* *}$ & & & \\
Normative commitment & $.362^{* *}$ & $.511^{* *}$ & & \\
Job satisfaction & $.345^{* *}$ & $.276^{* *}$ & $.374^{* *}$ & \\
\hline
\end{tabular}

**. Correlation is significant at the 0.01 level (1-tailed).

\section{Multiple Regression Analysis}

The multiple regression analysis was used to analyze the influence of organizational commitment on job satisfaction among the employees. The results indicated that $\mathrm{R} 2=0.215$, which means that organizational commitment explains $21.5 \%$ of the variance in job satisfaction with $\mathrm{F}=11.511, \mathrm{p}<0.000$. The remaining $75.5 \%$ was explained by other factors. In this case, organizational commitment significantly and positively influences the prediction of job satisfaction. Specifically, the organizational commitment that comprises affective commitment, continuance commitment and normative commitment influence job satisfaction with the beta values of $0.259,0.172$ and 0.213 respectively. Hence, Hypothesis 1, Hypothesis 2 and Hypothesis 3 were supported and indicated that organizational commitment significantly and positively influences job satisfaction among Polytechnic employees. Based on the results, the affective commitment had the highest influence on job satisfaction, followed by normative commitment. The factor that least influenced job satisfaction was continuance commitment. Table 3 shows the results of the multiple regression analysis of the study.

Table 3: Multiple Regression Analysis of the Study

\begin{tabular}{llllll}
\hline Model & B & SE B & $\beta$ & t & Sig. \\
\hline (Constant) & 2.076 & .319 & & 6.512 & .000 \\
Affective commitment & .170 & .056 & .259 & 3.041 & .003 \\
Continuance commitment & .142 & .071 & .172 & 1.993 & .048 \\
Normative commitment & .175 & .076 & .213 & 2.302 & .023 \\
\hline
\end{tabular}

$$
\text { Note: } \mathrm{R}^{2}=0.215, p<0.00 \text {. }
$$

\section{Discussion}

The main objective of this study was to look into the influence of organizational commitment and job satisfaction among the Polytechnic staff. Based on the empirical findings gathered, the result indicated that organizational commitment that comprises affective commitment, continuance commitment and normative commitment had a significant and positive influence on job satisfaction. The findings of this study is consistent with the research carried out by Chi, Yeh and Nguyen (2018) that revealed organizational commitment positively correlated with job satisfaction. The results are also congruent with Safi et al. (2015) that found a positive and significant connection between organizational commitment and job satisfaction. They also found a significant relationship between the elements of affective commitment and normative commitment and job satisfaction.

In this study, many aspects have been found to influence the significant and positive relationship between organizational commitment and job satisfaction. The findings revealed that most of the employees agreed that they are committed to the job because it is a necessity 


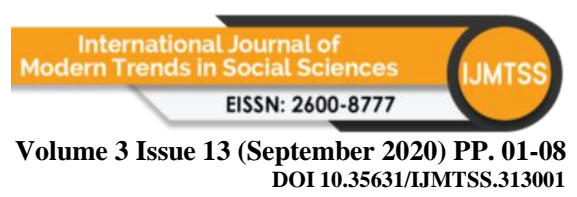

for them, and they have limited options to choose other jobs. Secondly, most of the employees are contented to spend the rest of their careers in the Polytechnic. Moreover, it is difficult for them to leave the organization right now, even if they wanted to do so. It is because leaving the organization requires personal sacrifice and other organizations may not be able to offer similar benefits like the Polytechnic. Besides that, the employees also agreed that it is obligatory to be loyal to the organization as it reflects the moral level of the person. Therefore, the employees are being taught to believe in the value of remaining loyal to one organization.

\section{Conclusion and Recommendation}

As a conclusion, this study found that organizational commitment significantly and positively influenced employee job satisfaction among the Polytechnic staff especially the employees of the Department of Tourism and Hospitality. These findings suggested that the limited choices that the employees have in opting for other jobs made the employees stay loyal to the Polytechnic. In addition, most of the employees enjoy the benefits that were provided by the Polytechnic and they are afraid to move to other organizations because they believed that they will not get similar benefits in the new workplace.

There were a few limitations in this study that are important to be considered. The first limitation was the variables used. The results of this study showed that there are other factors that influence job satisfaction besides organizational commitment. Perhaps, future research in this area can include factors such as job motivation, job involvement and employee attitudes. Secondly, this study focused only on employees in the Department of Tourism and Hospitality. Future researches can include other departments such as the Electrical Engineering Department, Mechanical Engineering Department, Department of Information Technology and Communication and Commerce Department. Lastly, this study focused only on the lecturers, thus research in the future can include management and non-management staff as well.

\section{References}

Abdullah, S., \& Majid, F.A. (2013). English language teaching challenges in Malaysia: Polytechnic lecturers' experience. World Applied Sciences Journal, 28(4), 540-547.

Ahmad, M. A-A., \& Jameel, A.S. (2018). Factors affecting on job satisfaction among academic staff. Polytechnic Journal, 8(2), 119-128.

Brayfield, A.H., \& Rothe, H.F. (1951). An index of job satisfaction. Journal of Applied Psychology, 35(5), 307-311.

Brislin, R.W. (1970). Back-translation for cross-cultural research. Journal of cross-cultural psychology, 1(3), 185-216.

Chi, H., Yeh, H., \& Nguyen, K.H. (2018). How job involvement moderates the relationship between organizational commitment and job satisfaction: evidence in Vietnam. Advances in Social Sciences Research Journal, 5(4) 136-148.

Culibrk, J., Delic, M., Mitrovic, S., \& Culibrk, C. (2018). Job satisfaction, organizational commitment and job involvement: The mediating role of job involvement. Frontiers in Psychology, 9, 1-12.

Greenberg, J., \& Baron, R.A. (2008). Behavior in Organizations: Understanding and Managing the Human Side of Work. Upper saddle River, NJ: Pearson Prentice Hall.

Jaafar, A.K. (2013). Transformasi politeknik fasa dua. Opening Speech at Kolokium Kecermelangan Akademik Pegawai Pendidikan Pengajian Tinggi, Kuala Lumpur.

Jabatan Pengajian Politeknik (2009). Hala tuju transformasi politeknik: Ke arah kelestarian penghasilan modal insan negara. Kementeria Pengajian Tinggi. 
Kalleberg, A. L. (1977). Work values and job rewards: A theory of job satisfaction. American Sociological Review, 42(1), 124-143.

Kumar, J.A. \& Muniandy, B. (2012). The influence of demographic profiles on emotional intelligence: A study on polytechnic lecturers in Malaysia. International Online Journal of Educational Sciences, 4(1), 62-70.

Meyer, J.P., \& Allen, N.J. (1991). A three-component conceptualization of organizational commitment. Human Resource Management Review, 1, 61-89.

Miah, M. M. (2018). The impact of employee job satisfaction toward organizational performance: A study of private sector employees in Kuching, East Malaysia. International Journal of Scientific and Research Publications, 8(12), 270-278.

Porter, L.W., Steers, R.M., Mowday, R.T. \& Boulian. P.V. (1974). Organizational commitment, job satisfaction and turnover among psychiatric technicians. Journal of Applied Psychology, 59, 603-609.

Şengür, D., \& Turhan, M. (2018). Prediction of the action identification levels of teachers based on organizational commitment and job satisfaction by using K-nearest Neighbors method. Turkish Journal of Science \& Technology, 13(2), 61-68.

Setiawan, D.P. \& Gunawan, H. (2018). The effect of job satisfaction and organization commitment to job performance through organizational citizenship behavior (OCB) as meditation variable (Empiris study on pt. Bank Mandiri at Jakarta). Business and Entrepreneurial Review, 18(1), 1-18.

Steers, R.M., Mowday, R.T., \& Porter, L.W. (1979). Employee Turnover and Post Decision Accommodation Processes (No. TR-22). Oregon University Eugene Graduate School of Management and Business.

Valaei, N., \& Rezaei, S. (2016). Job satisfaction and organizational commitment An empirical investigation among ICT-SMEs. Management Research Review, 39(12), 1663-1694.

Werang, B.R., \& Agung, A.A.G. (2017). Teachers' job satisfaction, organizational commitment, and performance in Indonesia: A Study from Merauke District, Papua. International Journal of Development and Sustainability, 6(8), 700- 711. 